\title{
Level of Integration among Supply Chain Members in Moving towards the Adoption of Sustainable Supply Chain Management in Ethiopian Manufacturing Industries
}

\author{
Assefa Balda*, Rajwinder Singh \\ School of Management Studies, Punjabi University, Patiala, India \\ Email: *shannonassefa@gmail.com,rajwindergheer@gmail.com
}

How to cite this paper: Balda, A., \& Singh, R. (2020). Level of Integration among Supply Chain Members in Moving towards the Adoption of Sustainable Supply Chain Management in Ethiopian Manufacturing Industries. American Journal of Industrial and Business Management, 10, 1181-1205. https://doi.org/10.4236/ajibm.2020.107080

Received: June 4, 2020

Accepted: July 19, 2020

Published: July 22, 2020

Copyright $\odot 2020$ by author(s) and Scientific Research Publishing Inc. This work is licensed under the Creative Commons Attribution International License (CC BY 4.0).

http://creativecommons.org/licenses/by/4.0/

\begin{abstract}
Sustainability is a multi-dimensional combination that enlarges the economic bottom line notion that focuses on efficiently and effectively usage of resources and realizing a return on investments, by adding social considerations and promoting superior ecological responsibility. The purpose of this study is to investigate the level of integration among supply chain members in moving towards the adoption of sustainable supply chain management (SSCM). In order to address this objective, descriptive research design was used based on cross-sectional survey. The data were collected through survey questionnaires from the top and middle-level managers of the sample firms. These sample firms were selected by proportional stratified sampling technique. From each sample firms three respondents were selected by using purposive sampling technique. Accordingly, valid data were collected from 420 participants from 146 large-scale manufacturing firms using self-administered questionnaires. The major findings are: despite to its limitation on jointly anticipating and developing plans for tackling potential problems on SSCM (environmental, social, and economic) large-scale manufacturing firms in Ethiopia were found highly integrated internally via information system and that enabled them to share up-to-dated information within firms. A strong level of integration with downstream supply chain members on strategic partnership, and in sharing adequate and quality information was also found. Integration on both suppliers and customers' involvement on environmental and social related issues of SSCM was found weak. On average the grand mean score value revealed that the level of integration among supply chain members in moving towards the adoption of SSCM for both external and internal was found moderate. Therefore, it can be concluded that the level of integration either externally or in-
\end{abstract}


ternally seems that the commitment of supply chain members (firms) is more on addressing their business or economic than environmental and social aspects of SSCM.

\section{Keywords}

Supply Chain, Sustainability, Sustainable Supply Chain Management, Integration, Collaboration, Manufacturing

\section{Introduction}

The concept of sustainability was first acknowledged at the global level by the report of the World Commission on Environment and Devolvement (WCED, 1987) which is a body of United Nations and it is also known as Brundtland commission. By coining, the term, sustainable development, Brundtland commission, is defined sustainability, as the "development that meets the needs of the present without compromising the ability of future generations to meet their needs". Even if the concept of sustainability is first introduced by the Brundtland commission, the supply chain sustainability topic has been of great interest both in academia and the practitioners' world in the last three decades. As stated by Dyllick \& Hockerts (2002) later on the 1992 Earth summit which is held in Rio de Janeiro, has increased widely the acceptance of Brundtland commission sustainability definition by various politicians, business leaders, and NGOs. In the course of few recent decades, high pressures from governments, clients, workers, investors, NGOs, volunteer groups, and other stakeholder bunches have incited companies to address the economic, ecological, and social ramifications of their activities (Morali \& Searcy, 2013).

Fabbe-Costes et al. (2011) stated that most countries in the world are interested in environmental issues and on the other hand, large-scale industries have been developed to increase their production capacity in order to respond to the free markets. Therefore, such industries development results in causing carbon emissions and various pollutions that affect the environment and the community health at large. In addition according to Simões (2014) currently, modern societies in industrialized countries demand high standards of living, which results in demanding high consumption of products and services. Therefore, for the production of these high demands of various products and services firms require huge amounts of resources that have been imposing several burdens on the societies and the planet/environment.

Due to various pressures, better attention was given to sustainability in the last few decades (Carter \& Rogers, 2008). Even if better attention is given for sustainability due to lack of adequate awareness (ignorance) a number of manufacturing industries have been continuously using natural resources without much consideration and they have been discharging wastes from their industries without much attention (Kottala et al., 2013). Further, Li \& Toppinen (2011) stated that 
the growing public interest in and global perception on environmental and social issues has intensified pressures on companies to effectively balance potentially conflicting stakeholder demands. However, balancing the conflicting pressure which is often created by firm-level of sustainable development among economic performance, environmental degradation, and social disruption is a main challenging task for firms (Matos \& Hall, 2007).

This article is organized in to eight sections. Accordingly the first section is introduction which highlights the concepts and backgrounds of sustainability. The second section discusses detailed literature review on level of integration among supply chain members. The third section presents materials and methodology applied in order to address the objective of the study. The forth section covers results and discussions on the level of integration among the supply chain members in moving towards the adoption of SSCM. The rest (fifth, sixth, seventh and eighth) sections presents conclusions, recommendations, limitations and future research direction, and acknowledgments respectively.

\section{Literature Review}

\subsection{Level of Integration}

In this globalized and competitive business world, it is impossible that for one organization to exist on its own without integrating with and dependent on the other organizations, which certainly enable them to influence and being influenced by others. Many scholars such as (Elkington, 1994; Seuring \& Mueller, 2008; Brindley \& Oxborrow, 2014) stated that, now a day's sustainability management is commonly understood that it has to be a comprehensive integration among the whole supply chain members, which means, in order to achieve the goal of sustainability it needs close collaboration among all supply chain partners such as suppliers, manufacturers, retailers and consumers.

\subsection{Supply Chain Integration (SCI)}

The main drivers of integration according to Handfield \& Nichols, (1999) are the information revolution; increased levels of global competition, creating a more demanding customer and demand-driven markets, and the emergence of new types of inter-organizational relationships. As stated by Akkermans et al. (1999) the foundation of integration is characterized by cooperation, collaboration, information sharing, trust, partnerships, shared technology, and a fundamental shift away from managing individual functional processes to managing integrated chains of processes.

According to Christopher (2005) the origin for the concept of supply chain integration is based on a system perspective which focuses on optimization of the whole system of the supply chain than focusing on optimizing a sub-system to realize better performance in the supply chain. Flynn et al. (2010) in their study clearly stated that supply chain integration (SCI) ranges from upstream (suppliers) integration to downstream (customers) integration and cross-functional 
(internal) integration within an organization. Further, they present that, SCI works on the fundamental principles of collaboration, free communication, high level of trust, shared decision-making, shared vision, and shared technology.

According to Vaart \& Donk (2006), supply chain partners need to be thoughtfully considered their domain of supply chain integration and close-cooperation, which depends on the nature/characteristics of their business. Cox Jr. (2001) boldly argues that not all relationships among the supply chain partners should be fully integrated and led to a valuable partnership. This is due to the type of partnership that should be developed among the supply chain partners specifically harmonized with the level of dependency between the supplier and customer. An empirical finding on a comprehensive site-based study conducted by Towill et al. (2000) on the European automotive manufacturing sector depicted that, as only $10 \%$ of the supply chains were observed as fully integrated. Further, another empirical survey research conducted in America by Poirier \& Quinn (2003) also shows that only $10 \%$ of supply chins had reached external (upstream and downstream) integration.

\subsection{Sustainable Supply Chain Integration (SSCI)}

Sustainable supply chain integration is the extent to which a manufacturer strategically collaborates with its supply chain partners and collaboratively manages its intra and inter-organization processes. The ultimate goal of sustainable supply china integration (SSCI) is to achieve economic, environmental and social aspects of sustainability by integrating flows of products and services, information, capital, and decisions, to provide the best value to various stakeholder groups (Wolf, 2011).

As discussed by different scholars in realizing sustainability, supply chain management (SCM) plays a very fundamental role. For example, as presented by (Mentzer et al., 2001; Srinivas, 2007) SCM has very deep and strong impact on the natural environment aspects of sustainability, due to it deals with the resources those are needed for the production of goods and services. They further stated that the buying practice of the customers also impacts suppliers' ability to improve their sustainability practices. According to (Brundtland Commission, 1987) this is due to customers (firms) use their purchasing power to inspire good social and environmental practices on companies across their supply chain.

As discussed by (Narasimhan \& Das, 2001; Wolf, 2011) adopting the concept of integration into sustainability and increased level of integration among the supply chain members helps to assess the impact of such integration activities on sustainability performance, it improves efforts and make supply chains become more sustainable and which leads to better achievement of SSCM performance.

\subsection{Types of Integration}

Integration can be studied at two different levels namely internal and external level of integration. Flynn et al. (2010) in their inclusive study conducted on "supply 
chain integration of Chinese manufacturing sector", stated that an internal integration is the extent to which various departments and/or functions within an organization are working closely, while external integration is to what extent supply chain partners are working closely with their suppliers and customers. Chan et al. (2012) also discussed that in order to achieve business objectives and to reach the desired level of customer satisfaction it is mandatory to have a deeper understanding and continual improvement both in internal integrations among functional areas within organization and external integration among upstream and downstream supply chain partners.

\subsubsection{Internal Integration}

As the best knowledge of the researcher, there are very few studies conducted on integration towards SSCM, while many studies were conducted on supply chain integration (SCI). Even if there are, many studies conducted on SCI the scope of the studies varies based on the authors and context of the study. For example (Narasimhan \& Das, 2001; Pagell, 2004) conducted their studies by focusing on the internal integration among various functional areas or departments within the organization. According to (Rummler \& Brache, 1995; Morash \& Clinton, 1998) it was evident that, before strengthening an external relationship with upstream and downstream supply chain partners, strong internal integration among all functional areas within organization is one of the fundamental milestones. Further Childerhouse \& Towill (2011), in their study on "arcs of supply chain integration" discussed that supply chain integration is highly commenced from a strong internal integration within an organization and then it passes through with external supply chain partners (i.e. suppliers and customers). Therefore, what can we understand from the above statements is that internal integration serves as a glue for building a strong external integration among the supply chain partners.

Flynn et al. (2010) boldly presented that, as internal integration breakdowns functional barriers and results in bringing cooperation and coordination among functional areas within organizations in order to meet customers' requirements. Further, it contributes a lot to the operational performance of firms too. According to Wolf (2011), statement higher levels of sustainable supply chain integration can be achieved when responsibility is shared across functions within an organization, and well-designed performance measurement and incentive systems have to be developed. In contrast to this incentive, systems that foster competition between functions seem to inhibit sustainability integration.

\subsubsection{External Integration}

According to Song \& Di Benedetto, (2008) external integration with customers (downstream supply chain partners) offers the opportunity to better understand customer expectations and their needs. At the same time as stated by (Koufteros et al., 2005; Flynn et al., 2010) sharing information with suppliers (upstream supply chain partners) through integration has also been claimed to improve 
performance because of more accurate plans of production and delivery. However, an empirical study conducted by Wolf (2011), depicted that as her entire sample case firms had problems in understanding and assessing the contribution that sustainable supply chain integration has on sustainability performance.

\section{1) External level of integration with customers}

According to an empirical evidence of Locke \& Romis (2007) depicted that customers are highly in need to understand the condition under which various products have been produced. Collins \& Dunne, (2007) also discussed that now a day's customers highly desired products that have been produced in an environmentally sustainable manner which enable firms to achieve SSCM. Rosi et al. (2013) based on their investigation on the influence of corporate social responsibility on supply chain management stated that supply chains those connected and interacted each other for only economic benefit reasons will have to collaborate for different needs of customers and consumers besides their economic benefits.

Proops et al. (1993) made an argument that consumers are responsible for all impacts of an economic system that supply goods and services irrespective of the boundary which occurs upstream of the consumers. Further, Hamilton \& Turton, (2002) states that the fulfillment of wants and needs for end-users or final consumption of goods and services are the driving forces that are responsible for most of the environmental, social and economic impacts.

\section{2) External integration with suppliers}

Concerning to external integration with upstream supply chain partners an empirical study conducted by Wolf (2011), on German manufacturing firms, shows that from the four case sample companies, Food Firm and Car Company has been working with strategic suppliers in the area of sustainability. Further, she stated that the Car Company's level of suppliers' integration goes to integrating its key suppliers into product development teams because the firm aimed to develop automotive vehicles that cause minimum carbon emissions throughout their lifecycle. Regarding level of integration on information sharing Wolf (2011), stated that information systems and processes have not been aligned in order to automatically track sustainability information, and the degree of information sharing depends on the supplier's willingness to share such information.

\subsection{Key Elements in Supply Chain Integration}

Even if there are many dimensions of supply chain integration Lee (2000) suggests three particularly powerful dimensions to supply chain integration that are most common and fundamentally used in different literatures. These are (1) organizational relationships or strategic partnership; (2) information integration; and (3) coordination and resource sharing. Further Ganesan, (1994) stated that trust is also another element in supply chain integration.

\subsubsection{Organizational Relationship/Strategic Partnerships}

As stated by Hall (2000) building strong relationships between SC partners is 
crucial for SSCM since each SC member must meet sustainability criteria. Many scholars such as (Hill, 2000; Simchi-Levi et al., 2003) discussed on considering the ongoing trends towards outsourcing, move to cheap labor countries, less resources (resource depletion), less physical infrastructures, strategic partnership is becoming very important among supply chain partners. According to Faisal (2010) creating long-term collaborative partnerships among the supply chain partners is one of a good opportunity to move and achieve sustainable competitive advantage. Further (Lee, 2008; Porter \& van der Linde, 1995) stated that in order to support sustainability initiatives it is important to build long-term strategic relationships among the supply chain members. As boldly presented by Engel (2011) in order to make the relationship among the supply chain partners more strong, healthy and exciting, a stage for problem-solving, for realizing mutual benefits through unceasing improvement, and control over SSCM performance objectives, active and strategic relationship management are very crucial. In addition, Handfield \& Nichols, (1999) discussed that two-way communication and mutual active engagement among the supply chain partners is very important for successfully adopting SSCM.

An empirical study conducted by Wolf (2011), on "Sustainable Supply Chain Management Integration; of the German manufacturing industry", shows that, in any of her sample case firms investigated, she could not find a clear supply chain sustainability strategy that was integrated into a broader corporate sustainability strategy.

\subsubsection{Information Integration}

According to (Cooper et al., 1997; Kaipia, 2007) for the smooth operation of supply chain integration, information integration is one of the strategic elements for all business organizations and they strongly focused on sharing information among the supply chain partners is highly important for the betterment of supply chain coordination.

According to Gulati (1999), one of the driving forces for companies to engage in collaborative relationships with their supply chain partners is information access on various issues. As presented by Preuss (2005), access information at different stages of a product's life-cycle regarding its impact on environmental and social aspects of sustainability is very important in SSCM. Seuring \& Muller (2008) stated that the kind of information access by the supply chain managers depends on the deeper flow of information along the supply chain and strong integration among the supply chain members.

Many scholars such as (DeGroote \& Marx, 2013; Sodero et al., 2013), discussed that both inter and intra organization integration through information technology positively affect their supply chain. In addition, Gold et al. (2010) stated that information access among the supply chain partners enhances the process of inter-organizational learning for creating inter-firms competitive advantages. However, according to Flynn et al., (2010) as it plays very strong roles in other forms of internal integration, information technology integration does 
not play as such a strong role in sustainability integration across functions within an organization and across the organization with supply chain partners externally. According to Simatupang \& Sridharan (2002), incentive alignment such as sharing risks, costs, and benefits, among the supply chain partners in a consistent manner enhances the level of integration among them.

Information sharing is very valuable to the supply chain members because it ultimately enables them to make better and synchronized decisions and actions based on reliable information shared (Davenport et al., 2001). According to Simatupang \& Sridharan (2002), in order to determine the contribution of information sharing to supply chain integration, its relevancy, accuracy, timeliness, and consistency has to be considered as a criterion.

\section{1) Level of information sharing}

As stated by (Childerhouse \& Towill, 2003) level of information, sharing refers to, the extent of proprietary and critical information is communicated among the supply chain partners. Further, they also suggested that, in order to make more effective and efficient the supply chain, it is very important to make available undistorted/factual and up-to-date information at every node/stage of supply chain along the supply chain. According to Moberg et al. (2002), the impact of information sharing on SSCM is based on the kind of information shared, the quality/accuracy of information shared, and the firm's ability in translating the shared information into sustainability strategy and using them into its operational activities.

\section{2) Quality of information sharing}

One of the key elements that enhance the level of integration among the supply chain partners towards the adoption of SSCM is the quality of information shared across the supply chain. According to (Monczka et al., 1998; Moberg et al., 2002) information, sharing is fundamental in supply chain management and the quality of information sharing aspects focuses on timeliness, adequacy, accuracy, as well as the credibility of information exchanged among the supply chain partners. However, Feldmann \& Müller (2003) discussed that when the supply chain partners have different interests and opportunities it affects the quality of information they share.

\subsubsection{Coordination and Resource Sharing}

As stated by many scholars the integration among companies enables them to obtain inter-organizational resources, which creates a sustainable competitive advantage over their competitors. For instance Flynna et al. (2010) stated that supply chain integration as a building block encompasses elements of joint collaboration, shared vision, high level of coordination, shared information and technology infrastructure among the supply chain partners. A study conducted by Junqueira (2010) on "logistics and SCM governance theory" discussed that supply chain management practices do have a significant impact on supply chain integration among supply chain partners and such integration builds a high level of mutual trust and collaboration among the supply chain partners for resource 
sharing.

\subsubsection{Trust among the Partners}

According to Ganesan, (1994) definition, trust is the willingness, belief, and the extent to which the partners focus on with whom they have confidence and will act in a way that produces positive outcomes and they do not want to undertake unexpected actions, which may result in negative outcomes. They also stated that trust is a prerequisite for creating strong integration among various supply chain partners in the supply chain. According to Wilson (1995), the concept of trust refers to credibility, confidence, and competence in fulfilling responsibilities and trustworthiness of promises. Further it is very fundamental in business relationships which involve that one partner will act in the best interest of the other partner. According to Gulati (1999) trust increases commitment, information sharing, inter-organizational learning and a common vision among the supply chain partners. As stated by (Spekman et al., 1998; Welford \& Frost, 2006; Gold et al., 2010) one of an inter-firm resource which is developed through the process of inter-organizational interaction is trust.

\section{Materials and Methodology}

Based on the purpose of the study descriptive type of research design was used. According to Creswell (2014) quantitative, qualitative or mixed approaches are the three research approaches in social researches. As data was collected in a close-ended questionnaire, which is developed in five (5) point-Likert-scale types, a quantitative research approach is used for this study. The items used in this study were adopted from various previous studies and developed by the researchers from theoretical literatures. To mention few of these sources (Ganesan, 1994; Cooper et al., 1997; Lee, 2000; Narasimhan \& Das, 2001; Childerhouse \& Towill, 2003; Pagell, 2004; Kaipia, 2007; Wolf, 2011; Childerhouse \& Towill, 2011) are the major ones.

According to Ethiopian Central Statistic Agency (CSA, 2016 report), based on the nature of products produced the manufacturing industries in Ethiopia were stratified in to fifteen categories. But this study focused only on four major manufacturing industry groups namely: 1) Food products and Beverage 2) Manufacturing of Textile 3) Tanning and dress of Leather, and 4) basic Iron and Steel manufacturing industries groups. Since it is difficult and unmanageable in terms of time and finance to address all supply chain members, and all of the manufacturing industry groups' in this study. Therefore, that is why this research confined to only the aforementioned four large-scale manufacturing industry groups operating in Ethiopia. Further justification for selecting these four industrial groups is that as they are prioritized in the Industrial development strategy of the Nation (Ethiopian Economics Association, 2011) and particular emphasis has given in the country first Growth and Transformation Plan (GTP) being implemented in the 2010/11 to 2014/15 time frame (Ethiopia. MoFED, 2010) and which is continued in the second GTP that is implemented from 2015/16-2019/20. 
The total number of large-scale manufacturing firms in the aforementioned four industrial categories throughout the country as a whole in the year 2014/15 is 405 (CSA, 2016 report). According to Kothari (2004), the size of the sample should neither be excessively large, nor too small. According to Cooper \& Schindler (2008), the ultimate test of a sample design is how well it represents the characteristics of the population it senses to present. Therefore, Yamane's (1967)'s formula as provided below was applied to determine the sample size for this study.

$$
n=\frac{N}{1+N(e)^{2}}
$$

where: $n=$ sample size; $N=$ population size; and $e=$ precision level/sampling error. Note: with a precision level (sampling error) of $e=5 \%$, and $N=405$ firms.

Therefore, through proportional stratified simple random sampling technique 201 sample firms were selected and then from each sample firm by using a purposive sampling technique three top and middle managers (respondents) were selected. These sample respondents were General or deputy manager, purchasing/supply chain manager, and the production/operations manager. Therefore, in total 603 questionnaires was distributed to 201 sample firms (i.e. $3 \times 201=$ 603). However out of 201 sample firms only 146 firms filled and returned questionnaires. Finally qualified (valid) questionnaires actually used for analysis were 420 , because about 18 questionnaires were invalid and rejected by the researchers.

After the relevant data collected from the sample respondents, it is very important and highly advisable to check the collected data consistency and validity to address the intended purpose of the study. Therefore, content validity was checked before the distribution of questionnaires and reliability (internal consistency) using Cronbach's alpha ( $\alpha$ ) was tested after data collection before data analysis. Therefore, the result of reliability test was illustrated in Table 1.

Table 1. Result of reliability test.

\begin{tabular}{ccc}
\hline Name of variable & No. of items & Cronbach's Alpha $(\boldsymbol{\alpha})$ \\
\hline Integration with Suppliers towards SSCM & 7 & 0.907 \\
Integration with Customers towards SSCM & 6 & 0.866 \\
Internal integration towards SSCM & 6 & 0.874 \\
\hline
\end{tabular}

\section{Results and Discussions}

As clearly presented under the literature part there are two fundamental types of integration namely external and internal level of integration. However, the external level of integration further classified into integration with suppliers (upstream) supply chain partners and integration with customers (downstream) supply chain partners. For example, Flynn et al. (2010) in their study boldly presented that, SCI ranges from upstream (suppliers) integration to downstream (customers) integration and cross-functional (internal) integration within the 
organization. Accordingly, the three aspects of supply chain partners' integration towards SSCM were assessed and analyzed descriptively.

\subsection{External Level of Integration with Suppliers}

In order to examine or asses, this type of integration, about seven items were developed by the researchers and the sample respondents were asked to rate the level of their firms integration with their upstream SC members in moving towards the adoption of SSCM along their supply chains.

As we can see from Table 2, it deals with large-scale manufacturing firms' level of integration with their Suppliers in moving towards SSCM. Accordingly the first item deals with a strategic partnership in moving towards the adoption of SSCM. As per the sample respondents' response, the mean score value $(\mathrm{M}=$ 3.31 ) with standard deviation ( $\mathrm{SD}=0.933$ ) was obtained. This implies that on average, the extent of the strategic partnership between firms of Ethiopian large-scale manufacturing industries with their suppliers towards the adoption of SSCM is at its moderate level and its standard deviation depicts that, there is no significant difference among the sample respondents.

From previous studies (Hall, 2000; Hill, 2000; Simchi-Levi et al., 2003; Lee, 2008; Faisal, 2010) boldly discussed that in order to support sustainability initiatives building long-term strategic partnership among the supply chain members is one of a good opportunity to move and achieve sustainable competitive advantage. It is due to the very critical role that supply chain partners plays in achieving SSCM. Further from an empirical study conducted by Wolf (2011), on "Sustainable Supply Chain Management Integration; of the German manufacturing industry" food firm and car company of her case studies depicted that as they are working with their strategic suppliers in the area of sustainability and their objective is to generate product and process innovations in sustainability.

Table 2. Firms level of integration with its suppliers towards SSCM.

\begin{tabular}{|c|c|c|c|}
\hline Item code & Firm's level of integration with its suppliers & Mean & SD \\
\hline LEIS1 & Level of a strategic partnership with your suppliers & 3.31 & 0.933 \\
\hline LEIS2 & $\begin{array}{l}\text { Level of trust and confidence with suppliers to share } \\
\text { SSCM-related information }\end{array}$ & 3.43 & 1.024 \\
\hline LEIS3 & $\begin{array}{l}\text { The extent of sharing adequate and quality information } \\
\text { with suppliers }\end{array}$ & 3.42 & 0.967 \\
\hline LEIS4 & $\begin{array}{l}\text { The extent of sharing relevant and timely information } \\
\text { with suppliers }\end{array}$ & 3.41 & 0.962 \\
\hline LEIS5 & $\begin{array}{l}\text { Degree of suppliers' involvement in environmental related } \\
\text { activities }\end{array}$ & 2.95 & 1.030 \\
\hline LEIS6 & $\begin{array}{l}\text { The extent of clear mutual understanding with your } \\
\text { suppliers over responsibilities on environmental issues }\end{array}$ & 2.94 & 1.031 \\
\hline \multirow[t]{2}{*}{ LEIS7 } & $\begin{array}{l}\text { Level of integration with your suppliers over issues related } \\
\text { to the social aspects }\end{array}$ & 2.87 & 1.012 \\
\hline & Grand mean & 3.19 & \\
\hline
\end{tabular}


So regarding the level of strategic partnership of suppliers and large-scale manufacturing firms in Ethiopia based on the finding it can be concluded that the current level of integration is somewhat promising but not sufficient for truly achieve better SSCM in their supply chain which is to some extent supported by the finding of Wolf (2011).

In the same table, the $2^{\text {nd }}, 3^{\text {rd }}$, and the $4^{\text {th }}$ items that deals about the level of trust and confidence to share SSCM-related information, the extent of sharing adequate and quality information, and the extent of sharing relevant and timely information with their suppliers scored mean value of $(\mathrm{M}=3.43,3.42$, and 3.41) with standard deviation value of ( $\mathrm{SD}=1.024,0.967$, and 0.962 ) respectively. Accordingly, the mean scores value of these three items showed that on average large-scale manufacturing firms level of integration with their upstream SC members is at its moderate level or to some extent they have an integration. Whereas their standard deviation implies that as there is a significant difference in the level of integration regarding trust and confidence but there is no significant inconsistency among the sample respondents regarding the adequacy and quality of information, and relevancy and timely information sharing.

From previous scholars Gulati (1999) stated that trust increases commitment, information sharing, inter-organizational learning and a common vision among the supply chain partners. That means a high level of trust is required in order to create integration and exert efforts to overcome various organizational barriers and to have synergies which result in improvements among companies. As per Davenport et al. (2001) information sharing is a very valuable to the supply chain members because it ultimately enables them to make better and synchronized decisions. Further (Moberg et al., 2002; Simatupang \& Sridharan, 2002), discussed that the contribution of information sharing to SCI on SSCM is depends on the kind of information shared, the quality or accuracy, relevance, timeliness, and consistency of information shared. Moreover, inadequate communication among the supply chain members is one of the main barriers that impede the implementation of SSCM (Seuring \& Muller, 2008).

Therefore, based on the above depicted previous research works and the analysis given above on the level of integration, regarding information-sharing aspects of this study it can be concluded that large-scale manufacturing firms in Ethiopia and their upstream supply chain partners have moderate level of integration in moving towards SSCM. Relatively it is better than the other aspects because their observed mean score values ranges (3.41 - 4.43), that means the level of external integration with suppliers in respect to information sharing is very promising.

The remaining last three items $\left(5^{\text {th }}, 6^{\text {th }}\right.$, and $\left.7^{\text {th }}\right)$ that discuss about, degree of suppliers' involvement in environmental related activities, extent of clear mutual understanding over responsibilities on environmental issues, and their level of integration over issues related to the social aspects of SSCM scored mean value of $(\mathrm{M}=2.95,2.94$, and 2.87) with standard deviation value of $(\mathrm{SD}=1.030,1.031$, 
and 1.012) respectively. This implies that even if there is moderate level of integration between the sample manufacturing firms in Ethiopia with their suppliers in moving towards the adoption of SSCM regarding suppliers' involvement on environmental issues, in having mutual understanding in responsibilities on environmental related issues and on social aspects of SSCM, relatively weak level of integration. All of their standard deviations depicted that there is a significant inconsistency among the sample respondents on these issues.

From previous studies, Carr \& Smeltzer (2000) discussed that manufacturers increase their control through collaboration with suppliers to make them more responsive to their customers' and environmental changes. In addition, Stonebraker \& Liao (2006) discussed that to reduce and deal with various environmental risks the SCI serves as the main management strategy. Further (Seuring \& Mueller, 2008; Chan et al., 2012; Brindley \& Oxborrow, 2014) stated that sustainability management has commonly understood as a comprehensive integration among the whole supply chain members and in order to achieve business objectives, to reach the desired level of customer satisfaction, it is mandatory to have a deeper understanding and continuous improvement among supply chain partners. Therefore, the above stated previous research works depicted that as all supply chain partners have responsibilities for SSCM and it needs their involvement and mutual understanding on sustainability issues. But the finding of this study depicted that relatively the level of external integration with suppliers concerning the extent of suppliers' involvement; mutual understanding and responsibilities on environmental, and social related issues were somewhat weak.

Finally, the grand mean score value $(M=3.19)$ was obtained. This amassed mean score value depicts that on average external level of integration of manufacturing firms in Ethiopia particularly the four targeted (Food and Beverage, Textile, Leather, and Basic Iron and steel) industries with their suppliers is at its moderate level. However, its mean value shows moderate relatively it is somewhat weak relative to the other type of integration and it needs more attention, strategies, and commitments that have to be given to realize SSCM at a high and sufficient level in their supply chain. In an empirical study conducted by Wolf (2011) on German manufacturing firms, finding shows that there is an integration with upstream supply chain partners of the case firms towards sustainability, but their overall level of sustainability integration was found low which is consistent with this finding.

\subsection{External Level of Integration with Customers}

The second category level of integration assessed in this study is the external level of integration of the selected large-scale manufacturing firms in Ethiopian with their customers (downstream) supply chain partners in moving towards the adoption SSCM. As depicted in Table 3 in order to address this level of integration six (6) items were adopted and the sample respondents were asked to rate the extent of their firms integration with customers in moving towards the adoption 
Table 3. Firms level of integration with its customers towards SSCM.

\begin{tabular}{|c|c|c|c|}
\hline Item code & Firm's level of integration with its customers & Mean & SD \\
\hline LEIC1 & Level of a strategic partnership with your customers & 3.65 & 0.839 \\
\hline LEIC2 & $\begin{array}{l}\text { Level of trust and confidence with customers' to share information } \\
\text { related to SSCM }\end{array}$ & 3.32 & 0.835 \\
\hline LEIC3 & The extent of sharing adequate and quality information with customers & 3.57 & 0.965 \\
\hline LEIC4 & Degree of customers' involvement in environmental related activities & 2.86 & 1.023 \\
\hline LEIC5 & $\begin{array}{l}\text { The extent of clear mutual understanding with your customers over } \\
\text { responsibilities on environmental issues }\end{array}$ & 3.08 & 1.013 \\
\hline \multirow[t]{2}{*}{ LEIC6 } & $\begin{array}{l}\text { Level of integration with your customers over issues related to social } \\
\text { aspects }\end{array}$ & 2.96 & 1.074 \\
\hline & Grand mean & 3.24 & \\
\hline
\end{tabular}

of SSCM.

As per the sample respondents' response on average the $1^{\text {st }}$ and $3^{\text {rd }}$ items which discuses about the level of strategic partnership, and the extent of sharing adequate and quality information with customers in moving towards the adoption of SSCM in their SC scored the highest and the second-highest mean value of $(\mathrm{M}=3.65$ and 3.57) with standard deviation of $(\mathrm{SD}=0.839$, and 0.965$)$ respectively. The standard deviation values depicted that as there is no significant difference among the sample respondents concerning these aspects of external integration with customers. As briefly presented under the literature part of this study, sharing information and building strategic partnerships are the two very fundamental elements in building a high level of integration among the supply chain partners for making synchronized decisions and in maintaining customers. The above mean score values denoted that as there is a strong/high level of integration between large-scale manufacturing firms in Ethiopia and their customers (downstream) supply chain partners regarding their strategic partnership, and adequacy and quality of information being shared.

From many studies conducted and discussed about the strategic partnership (Hall, 2000; Hill, 2000; Simchi-Levi et al., 2003; Lee, 2008; Faisal, 2010) stated that in order to support sustainability building a long-term strategic partnership among the supply chain partners is a good opportunity to move and achieve sustainable competitive advantage through the adoption of SSCM. Whereas, Davenport et al. (2001) regarding information sharing discussed that, as it is very valuable to the supply chain members because it ultimately enables them to make better and synchronized decisions and Simatupang \& Sridharan (2002), discussed that, the contribution of information sharing to SCI on SSCM depends on adequacy and quality or accuracy of information shard. This is due to inadequate communication among the supply chain members is one of the main hurdles that impede the implementation of SSCM (Seuring \& Muller, 2008).

Therefore, based on the aforementioned prior scholars, not only sharing of information among the supply chain members matter for the level of their inte- 
gration, what matters a lot is the adequacy and quality of information that they shared and the strategic partnership is very important to further strengthen their level of integration. Therefore, this study finding with respect to the strategic partnership, and adequate and quality of information sharing was highly consistent with the above-mentioned previous studies. Relative to external level of integration with suppliers this finding implies that large-scale manufacturing firms in Ethiopia have better and strong integration with their customers than suppliers in sharing adequate and quality information and in strategic-partnership.

In the same Table 3 the $2^{\text {nd }}$ and the $5^{\text {th }}$ items which deals with, Ethiopian large-scale manufacturing firms' level of trust and confidence to share SSCM-related information, and extent in having mutual understanding in responsibilities on environmental related issues with their customers (downstream) SC partners scored mean value of $(\mathrm{M}=3.32$ and 3.08) with standard deviation value of $(\mathrm{SD}=$ 0.835 and 1.013) respectively. This implies that the level of trust and confidence in sharing information related to SSCM, and on mutual understanding in responsibilities on environmental related issues is at its a moderate level.

From preceding studies Davenport et al., (2001) discussed that sharing information is invaluable to the supply chain partners for making synchronized decisions. Gulati (1999) discussed that trust increases commitment, information sharing, inter-organizational learning and common vision among the supply chain partners. This is due to that the kind, quality, and adequacy of information to be shared among the supply chain partners depend on the level of trust and confidence that they have on each other. Regarding the extent of clear mutual understanding over responsibilities on environmental issues from evidence of previous studies for instance (Locke \& Romis, 2007; Collins \& Dunne, 2007) finding depicted that, as customers are highly in need to understand the condition under which various products have been produced and they highly desired products that have been produced in an environmentally sustainable manner. Moreover, (Seuring \& Mueller, 2008; Chan et al., 2012; Brindley \& Oxborrow, 2014) stated that sustainability management as a comprehensive integration among the whole supply chain members and it is mandatory to have a deeper understanding and continuous improvement among the supply chain partners in order to achieve SSCM.

Therefore, it can be conclude from the above analysis that even if the level of external integration with customers regarding sharing adequate and quality information is high, the level of trust and confidence in sharing information related the social and environmental aspects of SSCM and mutual understanding on responsibilities on environmental issues with large-scale manufacturing firms in Ethiopian were at its moderate level. That means they are not confident enough in sharing such information to the extent it has to be for achieving SSCM. This indicates that a lot of tasks are expected to build their level of trust and confidence to share SSCM related information and increase their mutual understanding 
for making collaborative decisions to realize SSCM throughout their supply chains.

The $4^{\text {th }}$ and $6^{\text {th }}$ items which deals with degree of customers' involvement in environmental-related activities, and firms of Ethiopian large-scale manufacturing industries' level of integration with their customers over issues related to social aspects of SSCM scored relatively low mean values of $(M=2.86$ and 2.96) with standard score value of ( $\mathrm{SD}=1.023$ and 1.074) respectively.

From the earlier studies reviewed, Proops et al., (1993) made an argument that consumers are responsible for all impacts of an economic system, for supply of goods and services irrespective of the boundary which occur in upstream of the consumers. Further, Hamilton \& Turton (2002) discussed that the fulfillment of wants and needs for end users are the driving forces that are responsible for most of the environmental, social and economic impacts.

Therefore, what can be understood from these previous studies is that high level of customers' involvement and high level of responsibilities on influencing other supply chain partners in meeting economic, social, and environmental aspects of SSCM. That means when the customers do not accept environmentally un-friend products or operation, boycott manufacturing firms that are not fulfilling social compliances and properly manage/dispose products after usage they highly enhance SSCM performances. However, the finding of this study regarding the extent of customers' involvement in environmental related activities, and the level of integration over issues related to social aspects of SSCM between the large-scale firms of Ethiopian manufacturing industries and their customers implies that relatively it depicts low level of integration. That means, it needs more and more efforts to improve customers' involvement on environmental related issues and to build a strong integration for compliance of social aspects of SSCM in order to achieve high SSCM in their supply chains.

Ultimately, large-scale manufacturing firms in Ethiopia particularly (Food and Beverage, Textile, Leather, and Basic Iron and steel) industries external level of integration with downstream supply chain partners towards SSCM grand mean value ( $M=3.24)$ was obtained. Which depicts that on average external level of integration with downstream supply chain partners in moving towards the adoption of SSCM is at a moderate level. This implies that their level of integration is mainly focused on the business (economic) aspect rather than balanced SSCM aspects.

\subsection{Internal Level of Integration}

In the literature reviewed, many scholars for example, (Rummler \& Brache, 1995; Morash \& Clinton, 1998) stated that strong internal integration among all functional areas within an organization is one of the fundamental milestones towards the achievement of strong external supply chain integration and it increase organizational performance, which makes the organization stands at competitive position. In order to examine the extent of internal level of integration in 
moving towards the adoption of SSCM six (6) items was adopted and the sample respondents were asked to rate them.

From the six items adopted, to assess the internal level of integration of the selected large-scale manufacturing firms in Ethiopian, the first two items which discusses about, the level of information system integration, and the extent of up-to-date information sharing across the functional units/departments within an organization scored the mean value of $(M=3.66$ and 3.62) with standard deviation value of ( $\mathrm{SD}=0.895$, and 0.918 ) respectively. This implies that there is a high level of internal integration among functional areas within an organization via information systems, which enabled them to share up-to-date information in moving towards the adoption of SSCM. At the same time, their standard deviation value depicted that, as there is no significant difference among the sample respondents regarding their firms has a strong level of integration through information systems and in sharing up-to-date information.

From many preceding studies conducted by different scholars, Flynn et al. (2010) finding showed that as it plays strong roles in other forms of internal integration, information technology integration does not play as such strong role in sustainability integration across functions within organization and across organization with their supply chain partners externally. However, (DeGroote \& Marx, 2013; Sodero et al., 2013) discussed that intra-organization integration through information technology positively affects their supply chains. Regarding up-to-dated information sharing (Childerhouse \& Towill, 2003) stated that, in order to make more effective and efficient the supply chain, it is very important to make available undistorted and up-to-date information at every stage of the supply chain.

Therefore, as an internal level of integration is very fundamental for the external level of integration, the current level of internal integration obtained from such aspects about the large-scale manufacturing firms is very promising. As discussed above this finding was highly consistent with the findings of (Childerhouse \& Towill, 2003; DeGroote \& Marx, 2013; Sodero et al., 2013).

The $3^{\text {rd }}, 4^{\text {th }}$, and $5^{\text {th }}$ items in Table 4 deals about, degree of integration among functional units within organization to reduce their firms activities environmental impacts, the level of cross-functional integration for social compliance, and the extent of sharing responsibilities among functional units within an organization in moving towards the adoption of SSCM scored mean value of $(\mathrm{M}=$ $3.36,3.36$, and 3.21) with standard deviation value of ( $\mathrm{SD}=0.926,0.929$, and 0.978 ) respectively. This depicts that in moving towards SSCM to reduce negative impacts on environmental aspects of SSCM, in compliance with social aspects of SSCM, and in sharing responsibilities to achieve SSCM, the level of internal integration among various functional units within an organization in large-scale manufacturing firms of Ethiopia is at its moderate level.

Regarding internal level of integration, various scholars of previous studies such as (Rummler \& Brache, 1995; Morash \& Clinton, 1998; Childerhouse \& Towill, 2011) 
Table 4. Internal level of integration towards SSCM.

\begin{tabular}{clcc}
\hline Item code & \multicolumn{1}{c}{ Internal integration towards SSCM } & Mean & SD \\
\hline LII1 & $\begin{array}{l}\text { Level of Information system integration among internal functional } \\
\text { units }\end{array}$ & 3.66 & 0.895 \\
LII2 & $\begin{array}{l}\text { The extent of up-to-date information sharing across the functional } \\
\text { units }\end{array}$ & 3.62 & 0.918 \\
LII3 $\quad \begin{array}{l}\text { Degree of integration among functional units to reduce the } \\
\text { environmental impact of your firm's activities }\end{array}$ & 3.36 & 0.926 \\
LII4 & $\begin{array}{l}\text { Level of cross-functional integration for social compliance } \\
\text { LII5 }\end{array} \quad \begin{array}{l}\text { The extent of sharing responsibilities among functional units } \\
\text { within an organization to achieve SSCM }\end{array}$ & 3.32 & 0.929 \\
LII6 & $\begin{array}{l}\text { The extent of joint planning among functional units to anticipate } \\
\text { and solve SSCM-related problems }\end{array}$ & 2.78 & 0.978 \\
$\quad$ Grand mean & 3.33 & \\
\hline
\end{tabular}

given high emphasis for internal integration. They discussed that as the supply chain integration is highly commenced from a strong internal integration across all functional areas within organization strong level of internal integration is the fundamental milestone towards the achievement of strong external supply chain integration. Further Wolf (2011), stated that higher levels of sustainable supply chain integration can be achieved when responsibilities are shared across functions within an organization, and well-designed performance measurement and incentive systems have to be developed.

Therefore, according to the aforementioned previous scholars discussion even if having strong level of internal integration is very critical for building strong integration with the external supply chain members, based on the finding obtained from this study, the internal level of integration in large-scale manufacturing firms of Ethiopia in moving towards the adoption of SSCM to reduce negative environmental impacts, compliance in social aspects of SSCM, and in sharing responsibilities is moderate.

The last item, which deals with the extent of joint planning among functional units/departments to anticipate and solve SSCM-related potential problems scored relatively the lowest mean value of $(\mathrm{M}=2.78)$ with a standard deviation of $(\mathrm{SD}=$ 0.947). This implies that relatively internal level of integration, in large-scale manufacturing firms in Ethiopian is feeble (low) in respect to jointly planning to anticipate or forecast SSCM related problems that could result from their operations and in being proactively prepared to solve such problems. Its standard deviation shows that, as there is no significant inconsistency among the sample respondents on this issue.

An empirical study conducted by Wolf (2011), on "Sustainable Supply Chain Management Integration; of the German manufacturing industry", finding confirmed that, as there is a lack of corporate sustainability strategies within functional units of her case studied firms. Therefore, the above finding is consistent with Wolf (2011) finding. That means Ethiopian large-scale manufacturing firms 
have no clear mutual understanding/sustainability strategies jointly developed to forecast any negative impacts on SSCM by their firms operation and they are not well prepared proactively to overcome such potential problems.

Finally, the grand mean score value $(\mathrm{M}=3.33)$ concerning the internal level of integration in the selected large-scale manufacturing firms in Ethiopian in moving towards the adoption SSCM was obtained. This amassed mean score value indicates that on average, the internal level of integration within Ethiopian large-scale manufacturing firms is at its moderate level. Therefore, as it was stated by many scholars that external level of integration is highly depends on the level of internal integration, in order to execute SSCM practices in a more effective manner, to a greater extent various efforts and commitments are expected from Ethiopian large-scale manufacturing firms in order to build a strong internal and external level of integration to adopt SSCM along the whole supply chain.

\subsection{Correlation Analysis of the Internal and External Integration towards Sustainable Supply Chain Management}

Pearson's Correlation Coefficient was conducted to determine the relationship between firms' integration with its suppliers, customers, and internal integration within the organization in moving towards the adoption of SSCM of large-scale firms of Ethiopian manufacturing industries. It is conducted for assessing the strength and direction of association between the SC members. Accordingly, the result of correlation is presented in Table 5 .

The results in Table 5 indicates that large-scale manufacturing firms in Ethiopia have a positive and significant relationship with their suppliers (upstream) supply chain partners with $(r=0.695$, significant at 1 percent level of significance) and at the same time, they have also a positive and significant relationship with their customers (downstream) supply chain partners with $(r=0.795$, significant at 1 percent level of significance). Even if the selected large-scale firms of Ethiopian

Table 5. Pearson's correlation between suppliers, customers, and internal integrations.

\begin{tabular}{|c|c|c|c|c|}
\hline & Code & EXIS & EXIC & ILI \\
\hline \multirow{3}{*}{ EXIS } & Pearson Correlation & 1 & $0.646^{* *}$ & $0.695^{* *}$ \\
\hline & Sig. (2-tailed) & & 0.000 & 0.000 \\
\hline & $N$ & 420 & 420 & 420 \\
\hline \multirow{3}{*}{ EXIC } & Pearson Correlation & $0.646^{* *}$ & 1 & $0.797^{* *}$ \\
\hline & Sig. (2-tailed) & 0.000 & & 0.000 \\
\hline & $N$ & 420 & 420 & 420 \\
\hline \multirow{3}{*}{ ILI } & Pearson Correlation & $0.695^{* *}$ & $0.797^{* *}$ & 1 \\
\hline & Sig. (2-tailed) & 0.000 & 0.000 & \\
\hline & $N$ & 420 & 420 & 420 \\
\hline
\end{tabular}

${ }^{*}$ Correlation is significant at the 0.01 level (2-tailed). Where: EXIS = external level of integration with suppliers (upstream SC members); EXIC = external level of integration with customers (downstream SC members); ILI = internal level of internal integration among functional units. 
manufacturing industries do have positive and significant integration with both upstream (suppliers) and downstream (customers) as it can be seen from the correlation statistics value, relatively they had strong relationship/integration with customers (downstream) supply chin partners than suppliers (upstream) supply chin partners in moving towards SSCM. The third correlation coefficient shows a positive and significant relationship between suppliers (upstream) supply chain partners and customers (downstream) supply chain partners with $(r=0.646$, significant at 1 percent level of significance).

Therefore, correlation coefficient value representation (interpretation) is that the correlation coefficient values of this study regarding the association between upstream, downstream SC partners, and internal level of integration clearly depicted that there is a positive and substantial correlation on moving towards the adoption of SSCM.

\section{Conclusion}

Even though, collectively on average both externally with upstream and downstream SC members, and internally within organization among various functional units level of integration in moving towards the adoption of SSCM is moderate; relatively Ethiopian large-scale manufacturing firms appear to be encouragingly engaged in enhancing their intra-organizational than inter-organizational integration. Despite its limitation on jointly anticipating and developing plans for tackling potential problems on SSCM (environmental, social, and economic) large-scale manufacturing firms in Ethiopia are internally highly integrated via information system which enabled them to share up-to-dated information. Externally regarding strategic partnership and in sharing adequate and quality information they have high level of integration with their customers whereas, the level of integration on environmental and social issues of SSCM with suppliers and customers is somewhat weak.

Therefore, more specifically the level of integration either externally or internally seems that the commitment of firms is more on addressing their business or economic aspects than environmental and social aspects of sustainability. This conclusion was drawn from the fact that the result obtained on the level of integration regarding customers, and suppliers involvement on environmental-related activities, and compliance in social aspects of SSCM was relatively weak (low). Consequently, it indicates that still, they have a long distance to go for realizing SSCM because SSCM requires a strong or high level of integration among the SC members and balancing the economic, social, and environmental dimensions.

\section{Recommendations}

Large-scale manufacturing firms in Ethiopia shall first build strong internal level of integration within the firms functional units and then improve their external level of integration with upstream and downstream SC members (partners) in moving towards the adoption of SSCM. External integration can be improved 
through building active and strategic (long-term) relationship, build trust-based information sharing, developing win-win strategies like sharing risks, and other benefits (realizing mutual benefit) in a consistent manner, share knowledge, build cooperative relationships and strategies on how to be competitive as a supply chain than firms based competition to sustain their development.

Large-scale manufacturing firms in Ethiopia with their supply chain members shall go far from the current buy-sale business (economic) focused relationships to incorporate environmental as well as social aspects of SSCM for addressing SSCM along their supply chain.

\section{Limitations and Future Research Directions}

Despite to its valuable contribution this article was not without any limitation, however, such limitations provide opportunities for future research works. The major procedural limitations are: First the scope of this study was limited to only four large-scale manufacturing industries (Food and Beverage, Textile, Leather, and Basic Iron and steel) it does not incorporate other large-scale manufacturing industry groups. Second the data used under this study was collected by using only Likert-scale type which is perception based. The third limitation is the respondents where only from manufacturing firms, the study does not include suppliers and customers perceptions. Therefore, these shortcomings may limits to generalize the overall level of integrations among supply chain members of Ethiopian manufacturing industries in moving towards the adoption of SSCM and to some extent it limits the quality of the findings.

Therefore, the researchers suggest for future researchers that they shall incorporate other manufacturing categories and it is better other methods of data collections tools have to be used beside the Likert-scale type. Future researchers are also recommended that, to incorporate both suppliers and customers' perceptions to better explain the level of integration among the whole supply chain members in moving towards the adoption of SSCM.

\section{Acknowledgements}

We would like to extend our sincere gratitude to all sample participants (respondents) in the surveyed organizations for their cooperation by spending their invaluable time in filling up the survey questionnaires.

\section{Conflicts of Interest}

The authors declare no conflicts of interest regarding the publication of this paper.

\section{References}

Akkermans, H., Bogerd, P., \& Vos, B. (1999). Virtuous and Vicious Cycles on the Road towards International Supply Chain Management. International Journal of Operations \& Production Management, 19, 565-582. https://doi.org/10.1108/01443579910260883

Brindley, C., \& Oxborrow, L. (2014). Aligning the Sustainable Supply Chain to Green Marketing Needs: A Case Study. Industrial Marketing Management, 43, 45-55. 
https://doi.org/10.1016/j.indmarman.2013.08.003

Brundtland, G. H. (1987). Our Common Future-Call for Action. Environmental Conservation, 14, 291-294. https://doi.org/10.1017/S0376892900016805

Carr, A. S., \& Smeltzer, L. R. (2000). An Empirical Study of the Relationships among Purchasing Skills and Strategic Purchasing, Financial Performance, and Supplier Responsiveness. Journal of Supply Chain Management, 36, 40-54. https://doi.org/10.1111/j.1745-493X.2000.tb00250.x

Carter, C. R., \& Rogers, D. S. (2008). A Framework of Sustainable Supply Chain Management: Moving toward New Theory. International Journal of Physical Distribution \& Logistics Management, 38, 360-387. https://doi.org/10.1108/09600030810882816

Chan, H. K., Lettice, F., \& Durowoju, O. A. (Eds.) (2012). Decision-Making for Supply Chain Integration: Supply Chain Integration. New York, NY: Springer Science \& Business Media. https://doi.org/10.1007/978-1-4471-4033-7

Childerhouse, P., \& Towill, D. R. (2003). Simplified Material Flow Holds the Key to Supply Chain Integration. Omega, 31, 17-27. https://doi.org/10.1016/S0305-0483(02)00062-2

Childerhouse, P., \& Towill, D. R. (2011). Arcs of Supply Chain Integration. International Journal of Production Research, 49, 7441-7468. https://doi.org/10.1080/00207543.2010.524259

Christopher, M. (2005). Logistics and Supply Chain Management: Creating Value-Adding Networks (3rd ed.). London: FT Prentice Hall.

Collins, R. J., \& Dunne, A. J. (2007). A Rapid Supply Chain Appraisal Approach for Agribusiness Development Projects. ISHS Acta Horticulturae, 794, 73-80.

https://doi.org/10.17660/ActaHortic.2008.794.8

Cooper, D. R., \& Schindler, P. S. (2008). Business Research Methods (8th ed.). New York, NY: McGraw-Hill.

Cooper, M. C., Ellram, L. M., Gardner, J. T., \& Hanks, A. M. (1997). Meshing Multiple Alliances. Journal of Business Logistics, 18, 67-89.

Cox Jr., T. (2001). Creating the Multicultural Organization: A Strategy for Capturing the Power of Diversity. Washington DC: Jossey-Bass.

Creswell, J. W. (2014). Research Design: Qualitative, Quantitative, Mixed Methods Approaches (4th ed.). New Delhi, India: Sage Publications.

Davenport, T. H., Harris, J. G., De Long, D. W., \& Jacobson, A. L. (2001). Data to Knowledge to Results: Building an Analytic Capability. California Management Review, 43, 117-138. https://doi.org/10.2307/41166078

DeGroote, S. E., \& Marx, T. G. (2013). The Impact of IT on Supply Chain Agility and Firm Performance: An Empirical Investigation. International Journal of Information Management, 33, 909-916. https://doi.org/10.1016/j.ijinfomgt.2013.09.001

Dyllick, T., \& Hockerts, K. (2002). Beyond the Business Case for Corporate Sustainability. Business Strategy and the Environment, 11, 130-141. https://doi.org/10.1002/bse.323

Elkington, J. (1994). Towards the Sustainable Corporation: Win-Win-Win Business Strategies for Sustainable Development. California Management Review, 36, 90-100. https://doi.org/10.2307/41165746

Engel, B. (2011). 10 Ideas from Best-in-Class Supply Chain Organizations. CSCMP's Supply Chain Quarterly. http://www.supplychainquarterly.com/topics/Procurement/scq201101bestpractices/

Ethiopia. Central Statistical Agency (CSA) (2016). Large and Medium Scale Manufacturing Industries Survey.

Ethiopia. Ministry of Finance and Economic Development (MoFED) (2010). Growth and 
Transformation Plan (GTP). Addis Ababa: Ministry of Finance and Economic Development.

Ethiopian Economics Association (EEA) (2011). Report on the Ethiopian Economy. Addis Ababa: Ethiopian Economic Association.

Fabbe-Costes, N., Roussat, C., \& Colin, J. (2011). Future Sustainable Supply Chains: What Should Companies Scan? International Journal of Physical Distribution \& Logistics Management, 41, 228-252. https://doi.org/10.1108/09600031111123778

Faisal, M. N. (2010). Sustainable Supply Chains: A Study of Interaction among the Enablers. Business Process Management Journal, 16, 508-529. https://doi.org/10.1108/14637151011049476

Feldmann, M., \& Müller, S. (2003). An Incentive Scheme for True Information Providing in Supply Chains. Omega, 31, 63-73. https://doi.org/10.1016/S0305-0483(02)00096-8

Flynn, B. B., Huo, B., \& Zhao, X. (2010). The Impact of Supply Chain Integration on Performance: A Contingency and Configuration Approach. Journal of Operations Management, 28, 58-71. https://doi.org/10.1016/j.jom.2009.06.001

Ganesan, S. (1994). Determinants of Long-Term Orientation in Buyer-Seller Relationships. Journal of Marketing, 58, 1-19. https://doi.org/10.1177/002224299405800201

Gold, S., Seuring, S., \& Beske, P. (2010). Sustainable Supply Chain Management and Inter-Organizational Resources: A Literature Review. Corporate Social Responsibility and Environmental Management, 17, 230-245. https://doi.org/10.1002/csr.207

Gulati, R. (1999). Network Location and Learning: The Influence of Network Resources and Firm Capabilities on Alliance Formation. Strategic Management Journal, 20, 397-420. https://doi.org/10.1002/(SICI)1097-0266(199905)20:5<397::AID-SMJ35>3.0.CO;2-K

Hall, J. (2000). Environmental Supply Chain Dynamics. Journal of Cleaner Production, 8, 455-471. https://doi.org/10.1016/S0959-6526(00)00013-5

Hamilton, C., \& Turton, H. (2002). Determinants of Emissions Growth in OECD Countries. Energy Policy, 30, 63-71. https://doi.org/10.1016/S0301-4215(01)00060-X

Handfield, R. B., \& Nichols Jr., E. L. (1999). Introduction to Supply Chain Management. Englewood Cliffs, NJ: Prentice Hall.

Hill, T. (2000). Strategic Context and Managerial Analysis; Operations Management. Basingstoke, England: Macmillan Press.

Junqueira, R. V. (2010). Governance Structure and Supply Chain Management Practices in the Dairy Value Chain: A Comparative Study between New Zealand and Brazil. http://hdl.handle.net/10179/2263

Kaipia, R. (2007). Supply Chain Coordination: Studies on Planning and Information Sharing Mechanisms. Amsterdam: Helsinki University of Technology. https://aaltodoc.aalto.fi/bitstream/handle/123456789/2944/isbn9789512289493.pdf

Kothari, C. R. (2004). Research Methodology: Methods and Techniques (2nd ed.). New Delhi, India: New Age International (P) Ltd.

Kottala, S., Agrawal, D. R., \& Sharma, D. V. (2013). Sustainable Supply Chain Management Practices in Indian Manufacturing Firms: A Case-Based Research. In International Conference Business Analytics, Great Lakes Institute of Management, Chennai 24 December 2013.

Koufteros, X., Vonderembse, M., \& Jayaram, J. (2005). Internal and External Integration for Product Development: The Contingency Effects of Uncertainty, Equivocality, and Platform Strategy. Decision Sciences, 36, 97-133.

https://doi.org/10.1111/j.1540-5915.2005.00067.x 
Lee, H. L. (2000). Creating Value through Supply Chain Integration. Supply Chain Management Review, 4, 30-36.

Lee, H. L. (2008). Embedding Sustainability: Lessons from the Front Line. International Commerce Review, 8, 10-20. https://doi.org/10.1007/s12146-008-0026-4

Li, N., \& Toppinen, A. (2011). Corporate Responsibility and Sustainable Competitive Advantage in Forest-Based Industry: Complementary or Conflicting Goals? Forest Policy and Economics, 13, 113-123. https://doi.org/10.1016/j.forpol.2010.06.002

Locke, R. M., \& Romis, M. (2007). Improving Work Conditions in a Global Supply Chain. MIT Sloan Management Review, 48, 54-62.

Matos, S., \& Hall, J. (2007). Integrating Sustainable Development in the Supply Chain: The Case of Life Cycle Assessment in Oil and Gas and Agricultural Biotechnology. Journal of Operations Management, 25, 1083-1102. https://doi.org/10.1016/j.jom.2007.01.013

Mentzer, J. T., DeWitt, W., Keebler, J. S., Min, S., Nix, N. W., Smith, C. D., \& Zacharia, Z. G. (2001). Defining Supply Chain Management. Journal of Business Logistics, 22, 1-25. https://doi.org/10.1002/j.2158-1592.2001.tb00001.x

Moberg, C. R., Cutler, B. D., Gross, A., \& Speh, T. W. (2002). Identifying Antecedents of Information Exchange within Supply Chains. International Journal of Physical Distribution \& Logistics Management, 32, 755-770.

https://doi.org/10.1108/09600030210452431

Monczka, R. M., Petersen, K. J., Handfield, R. B., \& Ragatz, G. L. (1998). Success Factors in Strategic Supplier Alliances: The Buying Company Perspective. Decision Sciences, 29, 553-577. https://doi.org/10.1111/j.1540-5915.1998.tb01354.x

Morali, O., \& Searcy, C. (2013). A Review of Sustainable Supply Chain Management Practices in Canada. Journal of Business Ethics, 117, 635-658. https://doi.org/10.1007/s10551-012-1539-4

Morash, E. A., \& Clinton, S. R. (1998). Supply Chain Integration: Customer Value through Collaborative Closeness versus Operational Excellence. Journal of Marketing Theory and Practice, 6, 104-120. https://doi.org/10.1080/10696679.1998.11501814

Narasimhan, R., \& Das, A. (2001). The Impact of Purchasing Integration and Practices on Manufacturing Performance. Journal of Operations Management, 19, 593-609. https://doi.org/10.1016/S0272-6963(01)00055-9

Pagell, M. (2004). Understanding the Factors That Enable and Inhibit the Integration of Operations, Purchasing and Logistics. Journal of Operations Management, 22, 459-487. https://doi.org/10.1016/j.jom.2004.05.008

Poirier, C., \& Quinn, F. (2003). A Survey of Supply Chain Progress. Supply Chain Management Review, 7, 40-47.

Porter, M., \& van der Linde, C. (1995). Green and Competitive. Harvard Business Review, 73, 120-134.

Preuss, L. (2005). Rhetoric and Reality of Corporate Greening: A View from the Supply Chain Management Function. Business Strategy and the Environment, 14, 123-139. https://doi.org/10.1002/bse.435

Proops, J. L., Faber, M., \& Wagenhals, G. (1993). The Analysis of $\mathrm{CO}_{2}$ Emissions with Input-Output Methods. In Reducing $\mathrm{CO}_{2}$ Emissions (pp. 121-146). Heidelberg, Berlin: Springer. https://doi.org/10.1007/978-3-642-77792-9_9

Rosi, B., Cvahte, T., \& Jereb, B. (2013). The Influence of Corporate Social Responsibility on Supply Chain Management. Business Logistics in Modern Management, 13, 41-47.

Rummler, G. A., \& Brache, A. P. (1995). Improving Performance: How to Manage the 
White Space on the Organization Chart (2nd ed.). San Francisco, CA: Jossey-Bass, Inc.

Seuring, S., \& Müller, M. (2008). From a Literature Review to a Conceptual Framework for Sustainable Supply Chain Management. Journal of Cleaner Production, 16, 1699-1710. https://doi.org/10.1016/j.jclepro.2008.04.020

Simatupang, T. M., \& Sridharan, R. (2002). The Collaborative Supply Chain. The International Journal of Logistics Management, 13, 15-30. https://doi.org/10.1108/09574090210806333

Simchi-Levi, D., Kaminsky, P., \& Simchi-Levi, E. (2003). Designing and Managing the Supply Chain: Concepts, Strategies and Case Studies (2nd ed.). New York, NY: McGraw-Hill Education.

Simões, M. (2014). Social Key Performance Indicators-Assessment in Supply Chains. Doctoral Dissertation, Portugal: Technical University of Lisbon. https://pdfs.semanticscholar.org/7592/880e840b47f97c0f510b658715b60598dc00.pdf

Sodero, A. C., Rabinovich, E., \& Sinha, R. K. (2013). Drivers and Outcomes of Open-Standard Interorganizational Information Systems Assimilation in High-Technology Supply Chains. Journal of Operations Management, 31, 330-344.

https://doi.org/10.1016/j.jom.2013.07.008

Song, M., \& Di Benedetto, C. A. (2008). Supplier's Involvement and Success of Radical New Product Development in New Ventures. Journal of Operations Management, 26, 1-22. https://doi.org/10.1016/j.jom.2007.06.001

Spekman, R. E., Kamauff, J. W., \& Myhr, N. (1998). An Empirical Investigation into Supply Chain Management: A Perspective on Partnerships. Supply Chain Management, 3, 53-67. https://doi.org/10.1108/13598549810215379

Srinivas, H. (2007). The 3r Concept and Waste Minimization. http://www.gdrc.org/uem/waste/3r-minimization.html

Stonebraker, P. W., \& Liao, J. (2006). Supply Chain Integration: Exploring Product and Environmental Contingencies. Supply Chain Management, 11, 34-43. https://doi.org/10.1108/13598540610642457

Towill, D. R., Childerhouse, P., \& Disney, S. M. (2000). Speeding up the Progress Curve towards Effective Supply Chain Management. Supply Chain Management, 5, 122-130. https://doi.org/10.1108/13598540010338866

Vaart, T. V. D., \& Donk, D. P. V. (2006). Buyer-Focused Operations as a Supply Chain Strategy: Identifying the Influence of Business Characteristics. International Journal of Operations \& Production Management, 26, 8-23. https://doi.org/10.1108/01443570610636996

Welford, R., \& Frost, S. (2006). Corporate Social Responsibility in Asian Supply Chains. Corporate Social Responsibility and Environmental Management, 13, 166-176. https://doi.org/10.1002/csr.121

Wilson, D. T. (1995). An Integrated Model of Buyer-Seller Relationships. Journal of the Academy of Marketing Science, 23, 335-345. https://doi.org/10.1177/009207039502300414

Wolf, J. (2011). Sustainable Supply Chain Management Integration: A Qualitative Analysis of the German Manufacturing Industry. Journal of Business Ethics, 102, 221-235. https://doi.org/10.1007/s10551-011-0806-0

Yamane, T. (1967). Statistics, an introductory Analysis (2nd ed.). New York, NY: Harper and Row. 